\title{
PROF. D. POSTMA OOR DIE BESKULDIGING VAN SLAWERNY TEEN TRANSVAAL.
}

Die beskuldiging dat die Inboorlinge deur die Blanke bevolking in die Unie van Suid-Afrika onderdruk word, is nie iets van die twintigste eeu alleen nie. In die negentiende eeu was dit by uitstek die aanklagte wat teen die Boere gemaak is, veral as na 'n rede gesoek is om die on- 
afhanklikheid van die twee Republieke te vernietig. Dan is daar gewoonlik op die inboekstelsel gewys as op 'n bedekte vorm van slawerny, 'n stelsel wat egter nie alleen in die Republiek nie maar ook in die Engelse kolonies, die Kaap en Natal, in swang was. ${ }^{1}$ ) Maar die beskudigings het nie alleen van Engelse kant gekom nie. Twee persone wat as die ergste beskuldigers opgetree het, was predikante, ds. P. Huet wat in die jare $1858-1867$ predikant in Natal was en ds. F. Lion Cachet wat van 1861 tot 1865 ook predikant in Natal was en 'n groot vriend van ds. Huet, en van 1865 tot 1873 in Transvaal. Ds. Huet het twee geskrifte hieroor die lig laat sien, in 1860 sy Eéne Kudde en éen Herder waarin hy algehele gelykheid tussen blank en gekleurd op kerklik en maatskaplik gebied bepleit het, en in 1869 sy Het Lot der Zwarten in Transvaal, waarin hy die Transvaalse Boere van die mees krasse wreedhede teen die naturelle beskuldig het, as ook dat hulle slawehandelaars was en slawe aangehou het.

In die inleiding van laasgenoemde geskrif sê hy reguit dat sy doel daarmee is om Engeland te beweeg om die Republieke te vernietig en die gesag daarvan self in hande te neem. Ds. F. Lion Cachet het hierdie selfde beskuldiging herhaaldelik in die pers uitgespreek, soos in De Natal Bode, The Natal Mercury. The Natal Colonist, en in The Colonial Intelligencer, ' $\mathrm{n}$ negrofiele blad in Engeland. Oor die optrede van ds. Cachet word in 'n ander artikel gehandel.

Tydens die anneksasie-periode van Transvaal in die jare 1877 tot 1881 is die inboekstelsel gewoon deur die Britse Regering gehandhaaf en wat die slawerny aanbetref is daar in daardie tyd geen enkele slaaf in Transvaal vrygestel nie, omdat daar geen enkele slaaf was nie! Maar na die opheffing van die anneksasie in 1881 en die herinstelling van die Republiek het die beskuldigings van slawerny weer begin opduik. Na aanleiding hiervan het prof. D. Postma wat Transvaal goed geken het en tereg sê dat hy oor hierdie saak „recht van meepraten" het, in Die Afrikaanse Patriot van 8 April 1881 in 'n ingesonde stuk sy beskouings en bevindings meegedeel, en omdat dit belangrik is word dit hier in sy geheel afgedruk.

Burgersdorp.

Mijnheer de Redakteur,

Ik zie dat sommigen nu nog willen beweren, dat de annexatie van de Z.A. Republiek kan gerechtvaardigd worden wegens de slavernij, die door hen onder Boerenregeering gepleegd werden, hetwelk is tegen de Conventie van 1852; ja zelfs hooge ambtenaren in Engeland spreken zoo.

$\mathrm{Nu}$ gevoel ik mij ook geroepen daarover iets in 't licht te stellen,

1) Dr. W. J. Leyds: De Eerste Annexatie van Transvaal (1906), register onder "Slavernij in Z.A.". W. Kistner: The Anti-Slaverny Agitation Against The Transvaal Republic 1852-1868, Argief-jaarboek 1952 deel II bls. 197-278. - Oor die oorsprong van die inboek-stelsel sien P. J. Venter: Die Inboekstelsel, in Die Huisgenoot, 1 Junle 1934. 
zoo het $u$ behaagt dit schrijven in uw geërd blad op te nemen.

In de eerste plaats zeg ik: waarom komt men nu met die reden voor den dag? Is dat niet platweg muizennesten zoeken? Ten andere, had men die reden, waarom die dan niet aangevoerd bij de annexatie?

Toen hebben wij geene andere reden gehoord dan ,inherente zwakheid" van de Transvaal enz.

Maar zoo die misdaad dan al werkelijk bestond, nl. slavernij tegen de Conventie van 1852, waarom heeft de Engelsche Regeering - onder haar eigen Bestuur - niet de feiten geopenbaard en de vroegere Z.A. Republiek voor de Politieke rechtbank niet laten veroordeelen?

Niets van dat alles!

$\mathrm{Nu}$, nu men de annexatie voor de rechtbank des Publieks niet met iets anders kan verdedigen, nu komt men daarmede voor den dag.

Ik zou wenschen te vragen? Is dit gedrag Engeland waardig? Ik meene neen.

Ten derde wensch ik te verhalen wat ik persoonlijk van de zaak in het land zelf heb leeren kennen.

Sedert Nov. 1858 tot in Augustus 1866 heb ik in de Z.A. Republiek gewoond. En in mijne betrekking als Evangelie dienaar het land in zijne lengte en breedte gedurig doorreisd, tot in Lijdenburg, ZoutPansberg en Malmanie en Molopo. En dat, zooals ik zeg, gedurig die uiterste einden bezoekende. En werd toen goed huiselijk met de menschen bekend: dus meen ik recht van meepraten te hebben.

En ik verklaar plechtig:

Ik heb geen bewijs van slavernij ontdekt in al dien tijd op al mijne reizen bij naauwkeurige kennismaking met het personeel van dienstbaren.

Dat particulieren soms de wet ontduikten en tegen de wet handelden, mogen zij bewijzen die de beschuldiging doen; maar zulks kan men toch niet de regeering te last leggen, of men moest zulk een feit verklaagd hebben, en als dan de Regeering, of Rechter, het kwaad niet strafte, dan zou men recht hebben zich tegen de Regeering te beklagen.

Maar wie brengt zulk een bewijs te voorschijn? Mij is zulk een argument nog nooit bekend geworden, ofschoon ik nog steeds door mijne kerkelijke betrekking in goede kennis met dat land ben gebleven tot op heden.

Verder, wat mij bekend is van de verhouding van de gekleurde dienstbaren van dat land kan ik ook openhartig mededeelen.

1. Mij is bekend dat sommige stammen onder hun gebied en bescherming woonden op Goevernements grond of op particulier eigendom van burgers, onder de verplichting van een zeker getal mankaffers te laten dienen bij de burgers voor eene behoorlijke belooning. En dit geschiedde doorgaans onder het bestuur van den respectiven veldkornet.

Zoo had ook ik twee dienaars, die elkander om de maand vervingen, zoodat ik er maar altoos één in dienst had. Maar dan moet ik 
er nog bijvoegen, dat die twee zich daartoe bij mij vrijwillig voor een zekeren tijd verbonden, en dat accoord werd bij den veldcornet beschreven, gelijk ik het hier te Burgersdorp ook wel eens bij den Magistraat heb laten beschrijven.

Maar ik huurde ook wel eens iemand op mijne eigene manier zonder beschrijving, gelijk ik hier ook wel doe.

2. Worden daar ook wel onmondigen bij burgers ingeboekt tot hunne mondige jaren, even zooals ik het hier zie gebeuren.

Kort voor ik dat land verliet om hier te wonen, was ook een meidje van ongeveer 10 a 12 jaar bij mij als dienstbare ingeboekt volgens de wet des lands. En zij kwam met ons in Aug. van 1866 hier naar toe. Doch wij hadden hier nog maar weinige dagen gewoond, toen $\mathrm{mij}$ zelf vriendelijk door den publieken vervolger werd beduid, dat het mij volgens Engelsche wet niet geoorloofd was haar zoo te behouden. Ik bracht mijn document voort, maar mij werd gezegd, dat zulks hier niet gold. Ik, mij eerbiedig onderwerpende, gaf haar af. En kort daarna vernam ik dat ze bij den hoofdschout was ingeboekt. Althans, zij was daar als eene dienstbare, en wel tot haar spijt en leed, want zij had liever bij ons gebleven, zijnde reeds aan onze familie gehecht. En nog. ofschoon nu al lang met een vroegeren dienaar van mij getrouwd, blijft zij zich nog aan ons huis gehecht betoonen.

En nu voor ruim twee jaren werden wij burgers door ons (Engelsch) Gouvernement hier uitgenoodigd de overwonnen Galeka kaffers in dienst te nemen.

Ik heb toen ook weer een meidje van 10 a 12 jaren op het kantoor voor ons ingeboekt gekregen.

$\mathrm{Nu}$ begin ik te vragen: Zou dat misschien ook eene soort van slavernij zijn onder ons Engelsch Gouvernement? - Zegt men: Neen, dat moet bij de wet zoo geregeld en bestuurd worden. Wel, ik geloof dat ook in de gegeven omstandigheden met die nog onbeschaafde naties. Maar dan heeft eene vrije Republiek toch ook dat recht - of dien plicht - om zóó te doen als ons Engelsch Gouvernement doet.

(Een klein Gouvernment mag zeker wel een voorbeeld nemen aan een groot Gouvernement, vooral in 't goede bestuur des lands.)

Ziet, zoo ging het mij dáár, en zoo ging het mij hier.

Wie kan mij nu dat verklaren, dat zoo iets in de Transvaal slavernij moet heeten en hier niet voor slavernij gerekend wordt? Ik wordt nu dom.

Met erkentenis voor de opname,

Uw d.w.d.

D. Postma Sr.

Ds. Postma was regskape van aard, glad nie twissiek nie, en het hom nie graag in twissake gemeng nie. Hierdie brief van hom kan dan ook as ' $n$ eersterangse betroubare bron geld wat die beskuldigings van slavernij teen Transvaal aanbetref.

S.P.E. 